\title{
Learner Motivation and Teaching Aims of JAPANeSe Language Instruction IN SLOVENIA
}

\author{
Nagisa MORITOKI ŠKOF \\ University of Ljubljana, Slovenia \\ nagisa.moritoki@guest.arnes.si
}

\begin{abstract}
The purpose of this paper is to describe Japanese language teaching and the role of language teachers in Slovenia. Firstly, this paper shows the development and current situation of Japanese language teaching in Slovenia and Central Eastern Europe based on the statistics by the Japan Foundation survey from 2015 and preceding years. Next, the paper discusses the background and tendencies of the internal perspective with regards to the motivation for language learning, sustained by autonomous learning, and pluralism of languages and cultures in CE Europe Lastly, the importance of pre-service and in-service teacher training programs is emphasized, with the conclusion that the role of Japanese language teaching in Slovenia is not only to support the development of learners' linguistic proficiency, but also to offer learners and the educational institutions opportunities to act as social citizens, and organizations with a perspective that is wider than the European horizon of thought.
\end{abstract}

Keywords: Japanese language teaching; curriculum; articulation; motivation; plurilingualism and pluriculturalism

\section{Povzetek}

Namen članka je opis poučevanja japonskega jezika in vloge jezikovnih učiteljev v Sloveniji. V članku je najprej prikazan razvoj in trenutni položaj poučevanja japonskega jezika v Sloveniji ter v Srednji in Vzhodni Evropi na podlagi statističnih podatkov iz raziskave Japonske fundacije iz leta 2015 in iz let pred tem. Sledi razprava o ozadju in težnjah z notranjega zornega kota glede motivacij za učenje jezika, ki jih vzdržujejo avtonomno učenje in pluralizem jezikov in kultur v Srednji in Vzhodni Evropi. Nazadnje je $v$ članku poudarjen pomen programov usposabljanja tako na delovnem mestu kakor usposabljanj pred zaposlitvijo, z zaključkom, da pomen poučevanja japonskega jezika v Sloveniji ni le podpora razvoju učenčevega jezikovnega znanja, temveč tudi ustvarjanje priložnosti za učence in izobraževalne ustanove, da privzamejo vlogo družbenih državljanov in organizacij, s širšim miselnim obzorjem onkraj evropskih meja.

Ključne besede: poučevanje japonskega jezika; učni načrt; artikulacija; motivacija; večjezičnost in večkulturnost 


\section{Introduction}

Japanese language teaching in Slovenia started at the Slovenian Orientalist Society in the 1980's. The language course was intended for those who were interested in the Japanese language and culture, thus the participants ranged from high school students to elderly people, and with different backgrounds such as researchers, businessmen, and authors. Eventually, in 1995 the course expanded and merged with the Department of Non-European Studies (at present the Department of Asian Studies) at the Faculty of Arts, University of Ljubljana. It has been more than twenty years since the department's establishment, and its graduates are now playing an active role in the field of Japanese studies as researchers, or else are active in other fields of society connected to Japan. Such fields are the Japanese language teaching and culture clubs in primary and secondary schools in Slovenia, where graduates are involved as teachers and coordinators.

Concerning the present situation in Slovenia, the research focuses not only on higher education but also on other educational institutions such as primary schools, high schools and language courses where Japanese language and culture are taught, so that the whole image of Japanese language teaching in Slovenia is clearly presented. Next, the future perspective of Japanese language teaching in Slovenia is considered in connection with the differences at each education level, which needs to be articulated in language teaching between institutions. This paper reviews not only Slovenia but Central and Eastern Europe as well, since it is my personal belief that the concrete examples in other countries show a clearer standpoint of Slovenia and possibilities for future development of Japanese language teaching in Slovenia.

\section{Status of Japanese language teaching in CE Europe and Slovenia}

This chapter reviews the data of Japanese language teaching according to the survey by the Japan Foundation. The surrounding environment and the chronological transition of Japanese language teaching in Slovenia and CE Europe give us the fundamentals to consider the future image of Japanese language teaching in Slovenia.

\subsection{Number of Japanese language learners in CE Europe}

According to the survey by the Japan Foundation in 2015, the number of Japanese language learners around the world reached as high as 3.7 million, however the number nevertheless decreased by $8.3 \%$ compared to 2012 . The number of learners in CE Europe counts to 27,154 , which is less than $1 \%$ of learners around the world, and this number too has decreased by $3.9 \%$ since the 2012 survey. On the other hand, the 
number of language teachers has increased by $3.5 \%$ (from 1,300 to 1,346 ) and the number of institutions by $3.1 \%$ (from 386 to 398 ).

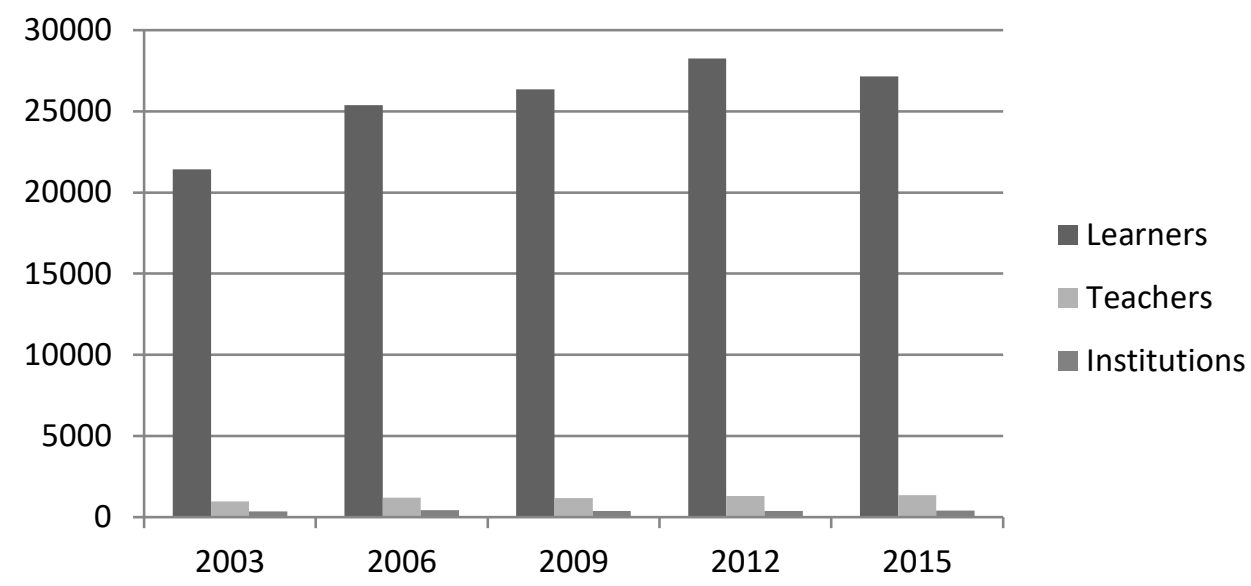

Figure 1: Number of learners, teachers, and institutions in CE Europe in the JF survey 2015.

Different trends can be found among those countries with a relatively large number of learners (Figure 2). The number of Russian learners has decreased as much as $24 \%$ compared to the 2012 survey, while the number of learners in Central European countries such as Poland, Romania, and Hungary has increased slightly, as shown below.

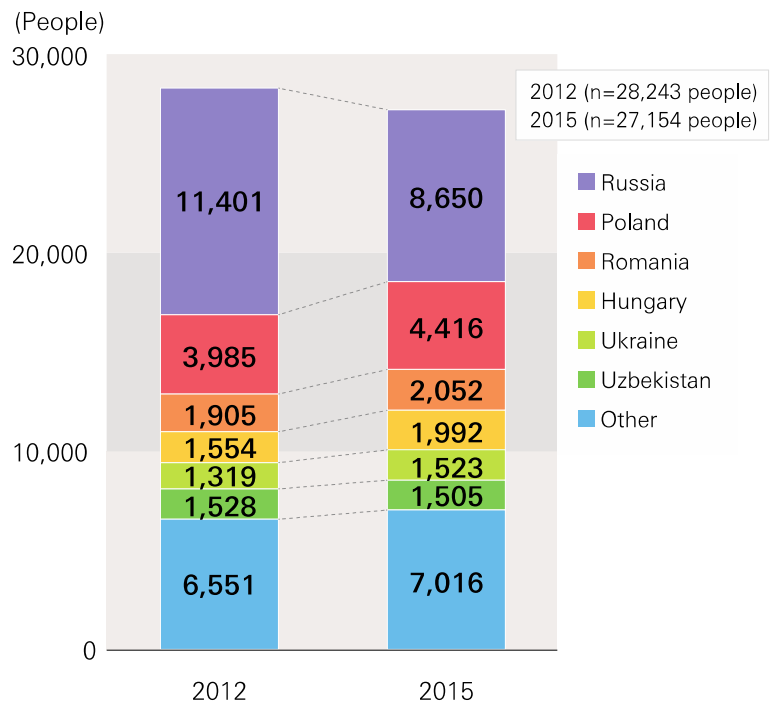

Figure 2: Number of Japanese-language learners in CE Europe according to the JF 2015 survey1.

\footnotetext{
${ }^{1}$ Number of Japanese-language learners in Eastern Europe (p. 39, Figure 2-9-2) from Survey Report on Japanese-Language Education Abroad 2015 (2017), Japan Foundation.
} 
Taking into account that the population of the age group in their late teens and early twenties has decreased in the last years, the growth in numbers of Japanese language learners is quite a strong trend in these countries.

\subsection{Number of Japanese language learners by level of education in CE Europe}

Figure 3 shows the numbers of learners and their ratios for each educational stage in CE countries. In countries with largest numbers of learners within the CE area, such as Poland, Romania, and Hungary, the ratio of learners at 'other institutions' is quite high as shown in Figure $3^{2}$. This shows that Japanese language teaching is conducted in various types of educational institutions, and in addition to curriculum programs. In the above mentioned countries this also means that it is conducted for a large number of learners.

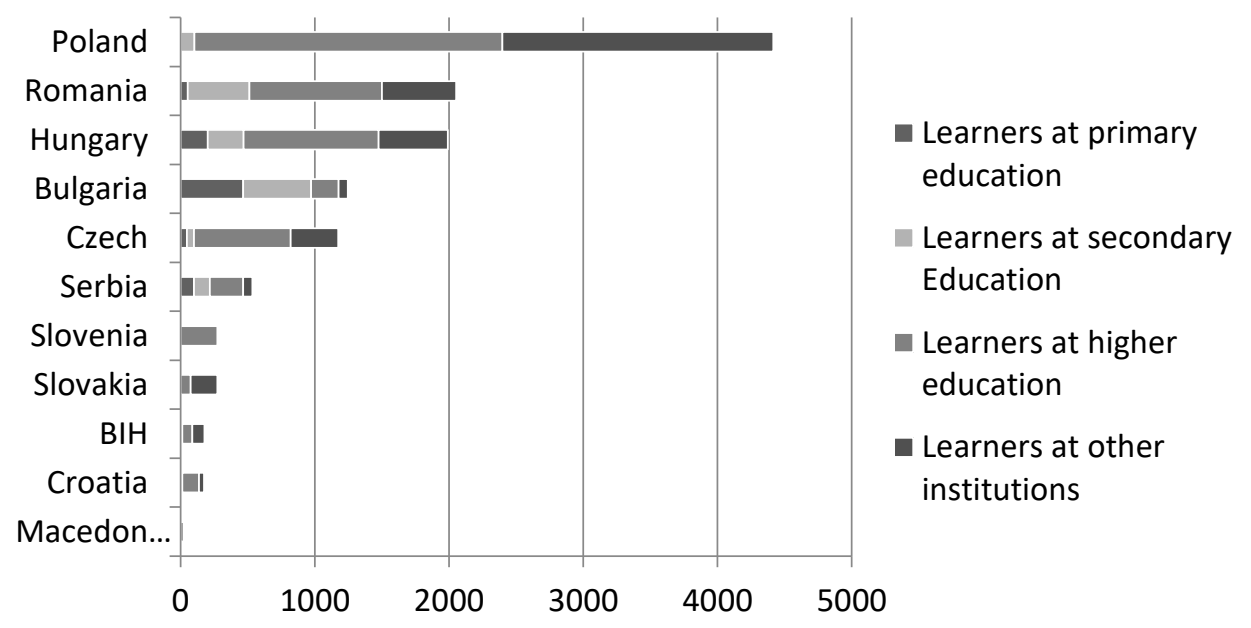

Figure 3: Number of learners by educational stage in CE Europe according to the $2015 \mathrm{JF}$ survey.

On the other hand, the data reveals relatively high numbers of Japanese language education at higher education compared to the numbers for Japanese language education in general in Poland, Romania, Hungary, Czech Republic, Slovenia, etc. In Romania, Hungary, Bulgaria, and Serbia Japanese language courses are implemented already into the primary education.

\footnotetext{
2 'Other institutions' includes private language schools, lifelong educational institutions run by public institutions, Japanese-language schools for children of people of Japanese ancestry, language courses run by higher educational institutions for the general public, Japanese-language courses for the general public run by the Japan Foundation, and in-house education offered by private companies and public institutions for their employees, etc. (The JF survey 2015, p.4)
} 
The JF survey covers only institutions for Japanese language education, and thus does not include learners studying by means of radio broadcasts and websites. In the last decades, a great number of learners is learning Japanese autonomously, mainly by using the materials provided on the Internet. Figure 4 shows the numbers of people registered as members of the Facebook community 'Nihongo', which involves those who are interested in Japanese language. The collected data has not been shown by the JF surveys so far.

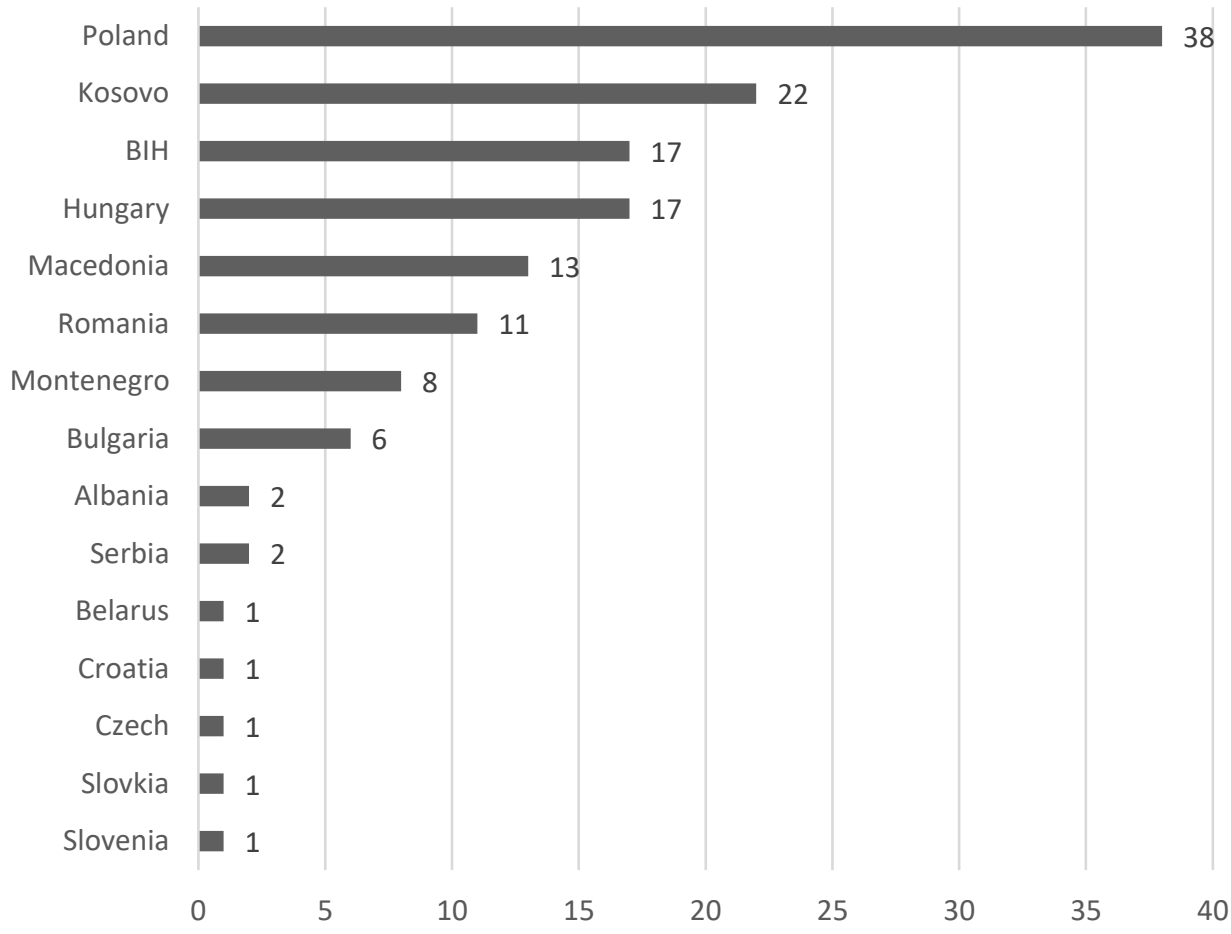

Figure 4: Number of members in the Facebook community group 'Nihongo', on 31 January 2016

It should be mentioned that this is not the number of 'Japanese language learners' but rather the number of all interested in Japanese language learning, which therefore includes both teachers and learners. It seems natural that the numbers of members in Poland and Hungary are quite large, while interestingly only a few members subscribe to the community group in Kosovo, Macedonia, and Montenegro. Although there were no learners and institutions in these countries according to the JF survey 2015, there certainly are people interested in learning Japanese.

One of the possible reasons why people interested in Japanese language teaching and/or learning are subscribed to such community groups is that there is no institution where they would be able to teach/learn the Japanese language. The learners there 
are autonomously seeking a place of Japanese language education and a place where they could communicate with other individuals with same interests.

\subsection{Status of Japanese language learning in Slovenia}

The Department of Asian Studies at the Faculty of Arts, University of Ljubljana has been the only institution of Japanese language learning and Japanese studies for more than two decades ${ }^{3}$. However, the overall picture of Japanese language learning has started changing after 2010. A Japanese language course was opened at the public school Pionirski dom Centre for Youth Culture in Ljubljana (Feher Malačič, 2018). Furthermore, a club on Japanese language and culture started in 2012 at one of the high schools in Ljubljana, and some private language schools established Japanese courses throughout Slovenia. Such activities are mostly conducted by the graduates of the Ljubljana's Department of Asian Studies. Since 2014, a primary school in the Primorska region ${ }^{4}$ has run a Japanese language and culture club for their pupils at the higher grades.

Official education guidelines for Japanese language teaching on the level of primary or secondary education in Slovenia have not yet been established. Among Asian languages, the guidelines for the Chinese language have been accredited at primary education in Slovenia, and the Chinese language can be taught in primary schools. Besides, several institutions at the level of kindergarten to high school have a Chinese language culture club and/or introduce it as a part of activities offered (Straus, 2018; Petrovčič, 2018).

To prepare well-considered education guidelines is one of the first steps towards establishing Japanese language teaching at Slovene educational institutions, but there exist other obstacles we have to deal with. First, elective subjects including foreign languages have to be selected by each individual school. Secondly, pupils and students have to express their interest in which electives they would want to choose, which sets the list of the elective subjects. This is a vital procedure at each school. It would not be possible for an educational institution to deliver all accredited subjects due to financial issues, finding teachers for the subjects, classroom and time restrictions to deliver the subject, etc. Thus, although a foreign language may be accredited by the Ministry, it does not mean that it is actually taught at the educational institution.

As mentioned above, a club on the Japanese language is progressing gradually and as a result, a few freshmen who already have Japanese learning experience enroll into the Department of Asian Studies at the University of Ljubljana every year. There is also the issue of articulation to include such students with the learning experience to

\footnotetext{
${ }^{3}$ See Hmeljak Sangawa (2018) for a further report on the development of Japanese studies at the Department of Asian Studies, the Faculty of Arts, University of Ljubljana, from its establishment in 1995 , including its former language course at the Slovenian Orientalist Society.

${ }^{4}$ Primorska region is in western Slovenia.
} 
regular classes at the higher educational institution. The articulation at the university has been carried out well so far. The freshmen with experience in Japanese language learning can take exams of the language subject, and when they pass the exams, they can get credits and move on to the language subject at the next level. However, this articulation system might become a problem in the future if learners' with different backgrounds and varying levels of proficiency enroll into the university course after having attended different types of courses at other institutions of Japanese learning and with autonomous self-study.

\section{Japanese language teaching in Slovenia}

As mentioned above, Japanese language teaching in CE Europe and Slovenia is gradually changing in time, and simultaneously with the change of social conditions. The need for Japanese language teaching is increasing among the youth in Slovenia and therefore, the establishment of guidelines for primary education Japanese teaching and well-considered contents of Japanese language teaching are urgent issues that need immediate attention. This section discusses the environment surrounding Japanese language teaching in Slovenia, and locates it in a curriculum and extracurriculum program according to the flow of language education in CE Europe.

\subsection{Motivation, internal perspective and its persistence}

The reason why one learns a foreign language differs from learner to learner. In case of Japanese language learning, the most general reasons for study in younger learners in the last decades are Japanese pop culture - including anime and manga; Japanese films and architecture for older learners, while the sound of the Japanese language appeals to learners of all ages. When thinking of reasons why learners choose to study Japanese, personal interests, outer perspectives such as social, economic and political topics become a motivating factor for learning.

In Slovenia, reflecting the economic and historical relations with Germany and Austria, German language is not only familiar but essential to general Slovene citizens. As seen in the Slovene curriculum of German language, language learning can provide possible economic and business opportunities to learners in the future ${ }^{5}$. On the other hand, Japan geographically stands at a distance from Slovenia and has much fewer economic ties and political relations compared to Germany. Japanese language learning can not promise to provide business opportunities in Slovenia. Even if any

\footnotetext{
${ }^{5}$ Predmetna kurikularna komisija za nemščino, Ministrstvo za šolstvo, znanost in sport. (2001). Učni načrt: izbirni predmet: program osnovnošolskega izobraževanja. Nemščina, Zavod RS za šolstvo.
} 
trends connected to economy and employment appear, such circumstances might be only temporary and may come to an end sooner or later.

On the other hand, the internal perspective, i.e. individual interests, such as J-pop and subculture in the case of Japanese language learning, can be more persistent than the outer perspective (Dörnyei, 2001a, 2001b, 2005, 2009). Considering the autonomous learning in CE Europe, a large number of micro-schools with higher quality curriculum continue to stimulate learners in various ways and to keep learners studying the language. Language learning is not carried out only in the classroom but also outside of it (Baldauf et.al., 2010) and thus, an educational institution is firstly located in a part of autonomous learning for lifelong language learning. A learner's motivation varies dynamically (Gardner \& Maclntyre, 1993) depending on the stage of learning and the learner's interests; the curriculum should maintain the learners' motivation and the balance of learning content. The guidelines need to function in the role of a learner's lifelong learning experience.

\subsection{Plurilingualism and pluriculturalism in Europe}

Another background of language learning is the plurilingualism and pluriculturalism in Europe. The plurilingualism and pluriculturalism are the abilities of an individual to use languages for the purposes of communication and to take part in intercultural interaction (Coste et al., 2009, p. 11). They are principles which are based on an individual's needs to use several languages and understand the multitier culture (de Florio-Hansen, 2011, p. 7). As the principle and goal of language learning are personal and citizenship education (Council of Europe, 2007), plurilingualism is not concerned with how a person has good skills to handle the target language as a native speaker, but how a learner can act using foreign languages as a social actor. Language proficiency in a society is not static but dynamic, which leads to the idea that, by learning several languages, language learning lasts throughout one's life (Starkey, 2002; Baldauf et.al., 2010).

Although Japanese language learning in Slovenia is not aimed at practical reasons as seen above, it has a valuable role from the perspective of the plurilingualism and pluriculturalism in Europe. The Japanese language, as one of the non-European languages such as Chinese, offers a view and dialogue beyond the traditional European frame $^{6}$. The substance focus on Asia provides for a 'comprehensive approach with a collaborative ethos' (Lo Bianco, 2005) and contributes to shifting the historical focus largely concentrated on Europe and the U.S. When we consider the international communication operating within a framework of political, economic and historical

\footnotetext{
${ }^{6}$ This point is clearly referred to in the guideline of Chinese language for primary education: Program osnovna šola kitajščina: Izbirni predmet: Učni načrt. Zavod RS za šolstvo in 2011.
} 
concepts and concerns (Parmenter, 2003), Asian language learning which brings diversity from the European perspective plays an important role in maintaining the balance of Slovenia's focus on the whole world.

\subsection{The aim of Japanese language teaching in the national education system}

In the Slovene curriculum, twelve languages are accredited as elective subjects for the last three years of primary school. Among them, the only Asian language is Chinese, while others are languages of countries neighboring Slovenia (Hungarian, Croatian, Italian), European languages (English, French, Germany, Spanish) and former Yugoslavian languages (Serbian, Macedonian), and Latin. These languages play a significant role in daily communication in Slovenia and this is the reason why they are accredited as elective subjects in primary schools.

The position of Japanese language in Slovenia differs from those languages mentioned, except for Chinese and Latin, and the aim of Japanese language teaching differs from the ones at each education level.

In higher education, where Japanese language learning has started in 1995 as a part of Japanese studies at the University of Ljubljana, Japanese language teaching is an essential part and the basis for Japanese studies. The aim of language teaching is, first and foremost, to foster future researchers of Japanese studies in the areas such as sociology, anthropology, linguistics and others. The knowledge of the language is required in order to comprehend references and research data in Japanese, which is sometimes written in classical Japanese or in a dialect. The ability to comprehend the references appropriately and present one's opinion logically in an academic way are required in order to participate in the language course. In fact, it is difficult to achieve such proficiency in the framework of a demanding curriculum during the three-year bachelor's programme and two-year master's programme at present, since the freshmen at Japanese studies usually have almost no Japanese proficiency, in comparison to other languages such as German and French. To supplement the lack of proficiency, study abroad, especially study in Japan, is obligatory as a part of the programme in higher education.

In secondary education, where the learners are interested in various topics and social matters, the aim of Japanese language teaching is to stimulate them to learn the Japanese language and topics connected to it and to embark on the autonomous and lifelong learning for the future. Considering the learners' age, Japanese language learning can be related to other subjects such as literature, history, or even physics. In other words, the topics connected to Japan and other Asian countries can be dynamically covered by regular subjects. Japanese language learning is seen as the first step to autonomously access the issues on Japan and provide the experience of any 
kind of otherness that can be considered intercultural experience (Alfred et. al, 2003, p. 6) in secondary education.

The aim of Japanese language teaching in primary education is supposed to be based on the idea of plurality and following diversity - the language should be in a position to support those ideas. The expected level of language proficiency is not for more than easy communication: greetings, expressing and understanding topics dealing with ones' family, ones' daily and school life. The stress is placed on Japanese teaching to know the Japanese as 'Others' through experiences using the Japanese language, and to prepare the terrain for plurilingualism and pluriculturalism. When the Japanese language is included as a subject in primary education, the goal of language learning needs not target high proficiency levels in writing and reading because of the unfamiliarity with the writing system in Japanese.

Japanese language teaching provides, besides language proficiency in Japanese for individual learners, a view and perspective from another part of the world for the educational institutions. Japanese language teaching is also a challenge of the plurality for the different education levels of Slovenia.

\section{Teacher training program}

When a well-considered guideline and curriculum are compared to hardware, a teacher is compared to a software. In order to put the guidelines and the curriculum effectively into practice, teachers have to function to the maximum of their knowledge, with their teaching skills and consideration for language teaching and support. As for teacher training, Lo Bianco (2009) states that the importance of teacher training is that 'a critical component of the strategy, perhaps the most important, is teacher education so that the ordinary preparation of teachers produces specialists able to design and implement high-quality programs' (Lo Bianco, 2009, p. 59).

Teacher training subjects have been offered under the Slovene curriculum at the University of Ljubljana recently. Future teacher training courses for Japanese language teaching, in accordance with the Slovene system, are required in order to enhance the content from the general pedagogy to special features in Japanese language teaching. It is important to combine the topics in Japanese language teaching with other subjects, to collaborate with colleagues teaching other subjects, to teach learners with learning difficulties and to teach in other institutions. Another issue is to maintain the level of language proficiency of in-service language teachers of Japanese at teacher-training seminars. To maintain that and at the same time gain new knowledge in teaching is not easy for a working teacher, and teacher-training seminars need to be well organized by a higher educational institution and/or an organized society of Japanese language teaching. 


\section{Conclusion}

This paper discusses Japanese language teaching and its background in Slovenia and CE Europe, as to establish an effective position for Japanese language teaching in Slovene education. Japanese language learning, when compared to other European languages, has fewer possibilities to bring learners practical benefits and opportunities such as business employment and economic success, yet it surely offers learners an understanding of plurality and diversity, and opportunities to act and behave as citizens with an understanding of the 'Other'.

It is of utmost importance that a learner willingly studies the Japanese language and its practical application in society. Language learning from the internal perspective on motivation has the characteristics of autonomy and, therefore, sustainability. Japanese language teachers are in a position to shape those perspectives, as well as to support a learner to learn the Japanese language, making their role essential to the development of Japanese language learning.

\section{References}

Baldauf, R. B. Jr., M. Li \& Zhao, S. (2010). Language Acquisition Management Inside and Outside the School. In B. Spolsky \& F. M. Hult (Eds.), The handbook of educational linguistics (pp. 233-250). John Wiley \& Sons.

Coste, D., Moore, D., \& Zarate, G. (2009). Plurilingual and pluricultural competence. Language Policy Division. Strasbourg: Council of Europe.

Council of Europe. (2007). From Linguistic diversity to plurilingual education: Guide for the Development of Language Education Policies in Europe. Strasbourg.

De Florio-Hansen, I. (2011). Towards Multilingualism Kassel university press $\mathrm{GmbH}$, Kassel.

Dörnyei, Z. (1994). Motivation and motivating in the foreign language classroom. The modern language journal, 78(3), 273-284.

Dörnyei, Z. (2001a). Teaching and researching motivation. Harlow: Longman.

Dörnyei, Z. (2001b). Motivational strategies in the language classroom. Cambridge:

Cambridge University Press.

Dörnyei , Z. (2005). The psychology of the language learner: Individual differences in second language acquisition. Mahwah: Lawrence Erlbaum.

Dörnyei , Z. (2009). The psychology of second language acquisition. Oxford: Oxford University Press.

Feher Malačič, K. (2018). Teaching of the Japanese and Chinese Language in Extracurricular Courses for Children, Adolescents and Adults. Acta Linguistica Asiatica, 8(1), 113-118. doi:10.4312/ala.8.1.113-118 
Hmeljak Sangawa, K. (2018). Japanese Language Teaching at Tertiary Level in Slovenia: Past Experiences, Future Perspectives, Acta Linguistica Asiatica, 8(1), 51-64. doi:10.4312/ala.8.1.51-64

Gardner, R. C. \& Maclntyre, P. D. (1993). A Student's Contributions to Second-Language Learning. Part II: Affective Variables. LanguageTeaching, 26, 1-11.

Lo Bianco, J. (2005). Asian Languages in Australian Schools: Policy Options. Melbourne Asia policy papers 7. The University of Melbourne. Retrieved from http://www.murdoch.edu.au/ALTC-Fellowship/ document/Resources/Lo Bianco Asian Languages.pdf

Lo Bianco, J. (2009). Second languages and Australian schooling. Australian Council for Educational Research. Victoria, Austoralia. Retrived from https://research.acer.edu.au/cgi/viewcontent.cgi?referer=\&httpsredir=1\&article=1007\& context=aer

Parmenter, L. (2003). Describing and defining intercultural communicative competence international perspectives. In M. Byram (Ed.), Intercultural competence (pp. 119-147). Council of Europe.

Petrovčič, M. (2018). Chinese as a Foreign Language in Slovene Upper Secondary Education and Outline of Curriculum Renewal. Acta Linguistika Asiatica, 8(1), 27-37. doi:10.4312/ala.8.1.27-37

Predmetna kurikularna komisija za nemščino, Ministrstvo za šolstvo, znanost in sport. (2001). Učni načrt: izbirni predmet: program osnovnošolskega izobraževanja. Nemščina, Zavod RS za šolstvo.

Starkey, H. (2002). Democratic citizenship, languages, diversity and human rights. Guide for the development of Language Education Policies in Europe From Linguistic Diversity to Plurilingual Education. Language Policy Division, Directorate of School, Out-of-School and Higher Education DGIV. Council of Europe, Strasbourg

Straus, B. (2018). Poučevanje tujih jezikov v slovenskem šolskem sistemu: prostor tudi za japonščino? Acta Linguistika Asiatica, 8(1), 9-26. doi:10.4312/ala.8.1.9-25

Survey Report on Japanese-Language Education Abroad (1993, 1998, 2003, 2006, 2009, 2012 in 2015), Japan Foundation. Retrieved from http://www.jpf.go.jp/i/project/japanese/survey/result/

Učni načrt - Izbirni predmet, Program osnovnošolskega izobraževanja (Francoščina, Hrvaščina, Italijanščina, Kitajščina, Latinščina, Madžarščina, Makedonščina, Nemščina, Ruščina, Srbščina, Španščina. Retrieved from http://www.mizs.gov.si/si/delovna podrocja/direktorat za predsolsko vzgojo in osnov no solstvo/osnovno solstvo/program/izbirni predmeti v osnovni soli/ 